\title{
(TiZr)N/(TiSi)N Maitilayer Nanostructured Coatings obtained by Vacuum Arc Deposition
}

\author{
S.V. Lytovchenko르, B.A. Mazilin¹, V.M. Beresnev¹, V.A. Stolbovoy², M.G. Kovalyova ${ }^{3}$, E.V. Kritsyna ${ }^{3}$, \\ I.V. Kolodiy'2, O.V. Glukhov ${ }^{4}$ L.V. Malikov ${ }^{5}$ \\ 1 V.N. Karazin Kharkiv National University, Kharkiv, Ukraine \\ 2 National Scientific Centre "Kharkiv Institute of Physics and Technology", Kharkiv, Ukraine \\ ${ }^{3}$ Belgorod National Research University, Belgorod, Russian Federation \\ ${ }^{4}$ Kharkiv National University of Radio Electronics, Kharkiv, Ukraine \\ 5 Scientific Centre of Physical Technologies of the Ministry of Education and Science and National Academy of \\ Science of Ukraine, Kharkiv, Ukraine
}

(Received 16 September 2018; revised manuscript received 22 October 2018; published online 29 October 2018)

\begin{abstract}
The paper investigates the structure and properties of nanoscale multilayer coatings based on (TiZr) $\mathrm{N}$ and (TiSi)N produced by vacuum arc technique. Also, it provides an analysis of the impact of partial pressure of nitrogen on structural and phase state of coatings. The nitride phases are strongly textured, crystallographic planes (111) of most grains are oriented parallel to the surface. Dimensions of the coherent scattering regions and values of micro-distortions of the lattice have been calculated. The hardness of coatings reached $37.1 \mathrm{GPa}$, and the adhesion fracture load exceeds $150 \mathrm{~N}$. The process technology ensures high uniformity of and a low defect rate in obtained coatings.
\end{abstract}

Key words: Nitride coatings, Multilayer coating, Composition of elements, Structure, Microhardness, Adhesive strength.

DOI: 10.21272/jnep.10(5).05041

PACS numbers: 61.46. - w, 62.20.Qp, 62-65. - g

\section{INTRODUCTION}

Materials based on nitrides of refractory metals make a unique foundation for protective coatings [1-3]. Improvement of physical, chemical, mechanical and tribological properties of coatings can be achieved through application of optimized processing technology and characteristics, e.g. thickness and number of periodic layers, gaseous pressure, and bias potential in deposition.

One of the most promising trends in improvement of performance of nanostructured nitride coatings is creating of multilayer compositions with nanometer-thick layers [4-6]. In such a case, properties of the system, including emerging internal stresses and their concentration, or crack growth and proliferation, can be significantly changed through interchange of two and more layers of material with different stress-strain performance, which makes it possible to increase fracture toughness in such materials $[7,8]$.

The paper provides experimental findings on production and investigation of stress-strain properties of multilayer vacuum arc coatings of (TiZr) $\mathrm{N} /(\mathrm{TiSi}) \mathrm{N}$ type which are composed of nanometer-thick layers.

\section{MATERIALS AND TECHNIQUES OF INVESTIGATION}

The samples with coatings were obtained by the vacuum arc technique on an upgraded Bulat unit (Fig. 1). Deposition of (TiZr)N/(TiSi)N coatings was done from two sources in constant spinning of the fixed samples at the rotation speed of $8 \mathrm{rpm}$ with a fixed stop at each of the two cathodes for 20 seconds.

$\mathrm{Ti}_{75} \mathrm{Zr}_{25}$ and Ti94Si6 alloys were used as evaporated materials, and nitrogen was used as a reactive gas. The substrates of $15 \times 15 \times 2.5 \mathrm{~mm}^{3}$ were cut out of $12 \mathrm{X} 18 \mathrm{H} 9 \mathrm{~T}$ sheet steel with the surface roughness

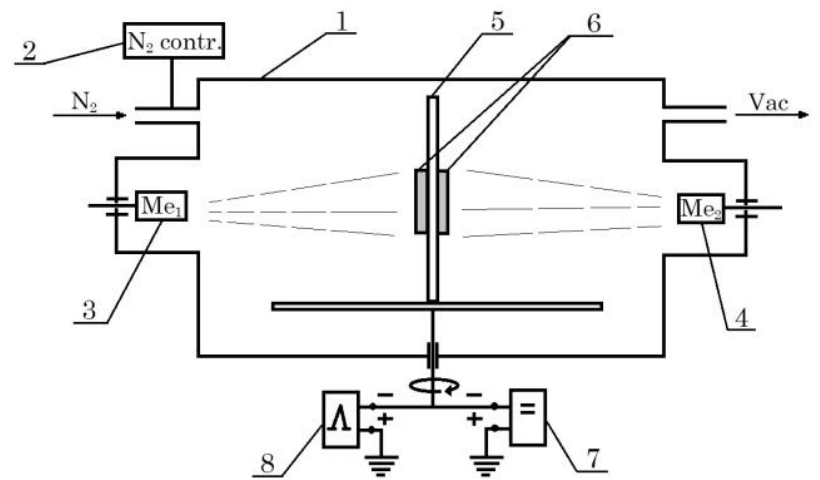

Fig. 1 - Diagram of installation for coating formation: 1 vacuum chamber; 2 - automatic system for pressure control of nitrogen; 3 - TiZr evaporator; 4 - TiSi evaporator; 5 - substrate holder; 6 - samples; 7 - direct current source; 8 - highvoltage impulse generator

$R_{a}=0.09 \mu \mathrm{m}$. The pressure of nitrogen in the chamber in deposition $\left(P_{\mathrm{N}}\right)$ was $0.13 \mathrm{~Pa}$ or $0.6 \mathrm{~Pa}$, while the bias potential $U_{b}$ supplied to the substrate was $-200 \mathrm{~V}$. During the experiment, there were 90 layers of coating applied, each of which contained two (TiZr)N/(TiSi)N interlayers with the total thickness $40-50 \mathrm{~nm}$. The cumulative thickness of the whole multilayer coating made about $4.5 \mu \mathrm{m}$. The structure and element composition of the nanostructured multilayer coatings were evaluated using FEI Quanta 200 3D and FEI Quanta 600 FEG scanning electron microscopes. The phase composition of nanostructured multilayer coatings was examined by X-ray method using a DRON-4M diffractometer in $\mathrm{Cu}-\mathrm{Ka}$ radiation. The surface microhardness tests were performed using an AFFRI DM-8 automated microhardness tester. The adhesive strength measurement was done by sclerometry using a REVETEST CSM Instruments scratch tester. 


\section{RESULTS AND DISCUSSION}

The morphology of the surface of coatings has a rather rugged texture which is attributed to drop constituents found in them (Fig. 2). Comparison of the morphology of the surface of samples obtained at different nitrogen pressures $(0.13 \mathrm{~Pa}$ and $0.6 \mathrm{~Pa})$ shows that at a high pressure the number of drop constituents decreases (Fig. 2). This is especially true with active gases in the vacuum chamber which, in combination with the evaporated material, form refractory compounds.

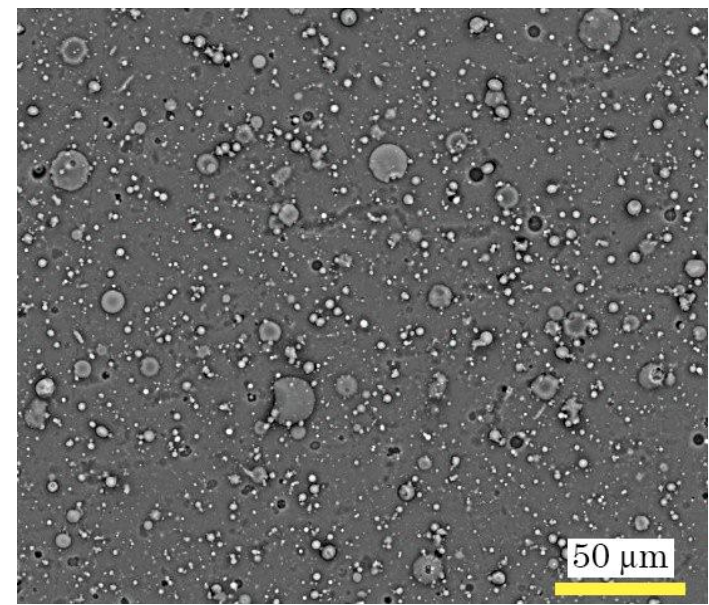

a

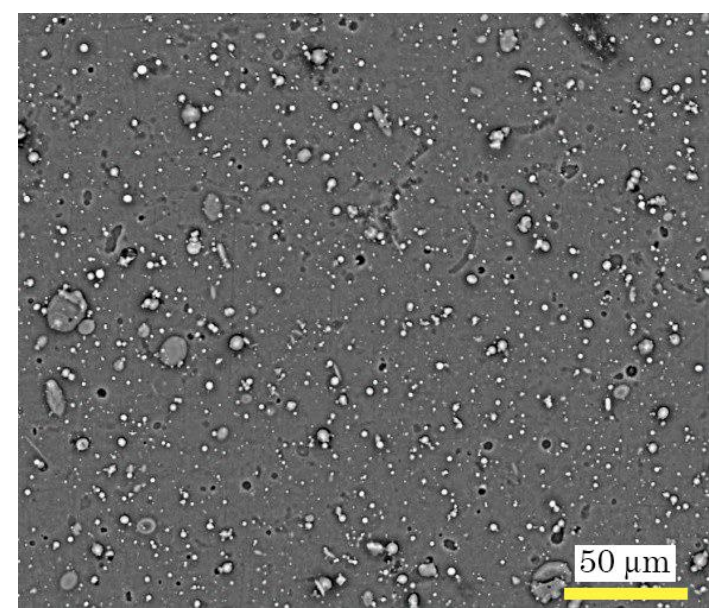

$\mathrm{b}$

Fig. 2 - Microstructure of the surface of (TiZr)N/(TiSi)N coatings obtained at bias potential $U_{b}=-200 \mathrm{~V}$ and at different nitrogen partial pressures: a) $P=0.13 \mathrm{~Pa}$; b) $P=0.6 \mathrm{~Pa}$

Fig. 3 shows images of cross-sections of (TiZr) N/(TiSi) N multilayer coatings. It can be seen that thin layers have fairly high uniformity of deposited condensates and insignificant imperfection in thickness.

As revealed by the microanalysis findings (Table 1), the multilayer coatings have elements, which are present in evaporated materials (titanium, zirconium, silicon), and elements of the substrate (iron). The data of the chemical analysis also indicate that there are variations in the concentration of elements in the coating composition depending on deposition conditions.

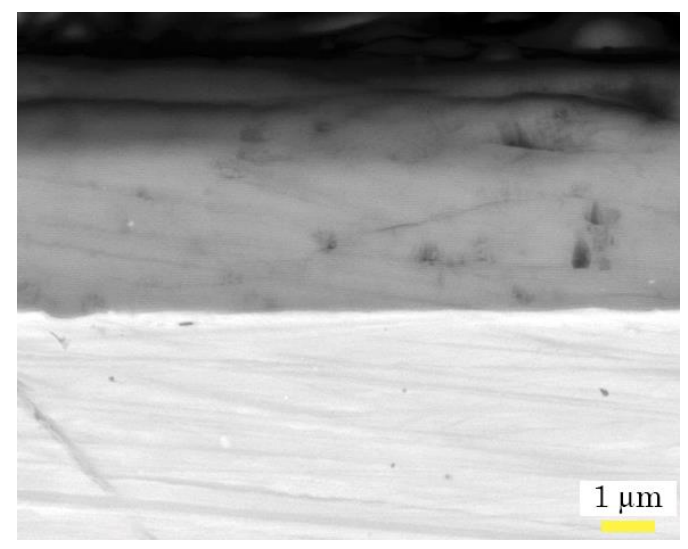

a

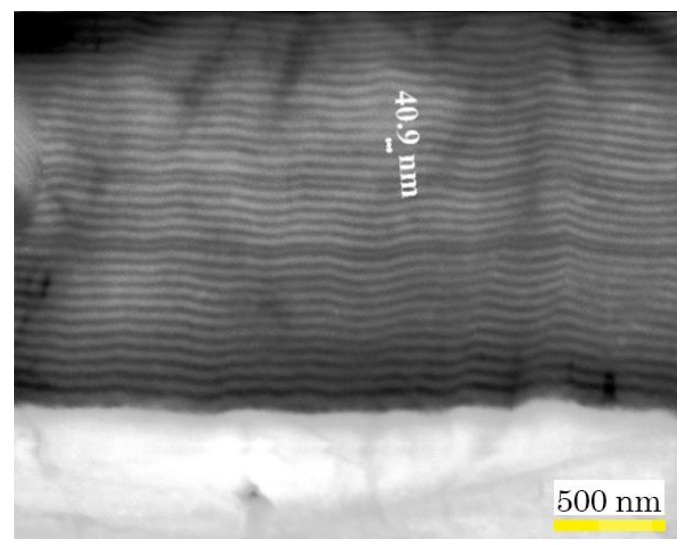

b

Fig. 3 - Cross-sections of (TiZr)N/(TiSi)N multilayer coatings: a) a general view of the fracture of a coated sample; b) an enlarged fragment of the cross-section of a multilayer coating, SEM

Table 1 - Coatings chemical analysis data

\begin{tabular}{|l|c|c|c|c|c|}
\hline \multirow{2}{*}{$\begin{array}{c}\text { (TiZr)N/(TiSi)N } \\
\text { Coatings }\end{array}$} & \multicolumn{5}{|c|}{ Elements, At.\% } \\
\cline { 2 - 6 } & $\mathrm{N}$ & $\mathrm{Si}$ & $\mathrm{Ti}$ & $\mathrm{Zr}$ & $\mathrm{Fe}$ \\
\hline $\begin{array}{l}\text { Series } 1 \\
P=0.13 \mathrm{~Pa}\end{array}$ & 48.86 & 0.73 & 45.63 & 4.38 & 0.40 \\
\hline $\begin{array}{l}\text { Series } 2 \\
P=0.6 \mathrm{~Pa}\end{array}$ & 49.05 & 0.71 & 45.98 & 3.93 & 0.33 \\
\hline
\end{tabular}

The above findings suggest that the high bias potential $\left(U_{b}=-200 \mathrm{~V}\right)$ increases the energy of falling particles and thus increases the X-ray component of the plasma flow, which results in an increase of titanium and ammonium in the coating - elements strongly prone to formation of nitrides.

Fig. 4 shows typical fragments of X-ray patterns of samples with (TiZr) $\mathrm{N} /(\mathrm{TiSi}) \mathrm{N}$ multilayer coatings. There are lines from elements of substrate (steel) in the X-ray diffraction patterns of all patterns. All nitride phases are strongly textured, the crystallographic planes (111) of most grains are oriented parallel to the coating surface.

The research shows that there are two phases in coatings. However, due to proximity of periods of the two phases which form multilayer coatings it is sug- 
gested that their spectra are overlaid. In condensation of coatings, the two phases are formed in the surface layers, the first of which is a solid solution of (TiZr)N based on a NaCl-type cubic lattice, and the second is a (TiSi) N compound.

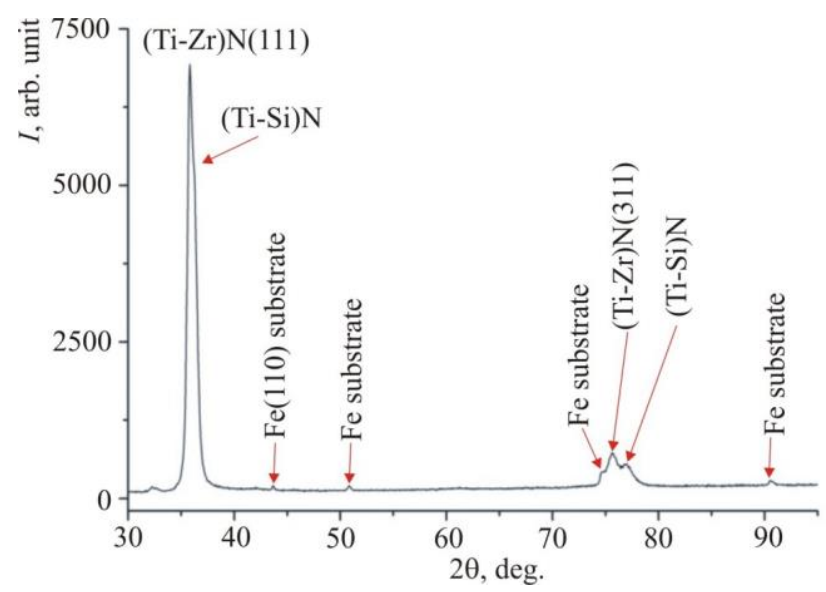

a

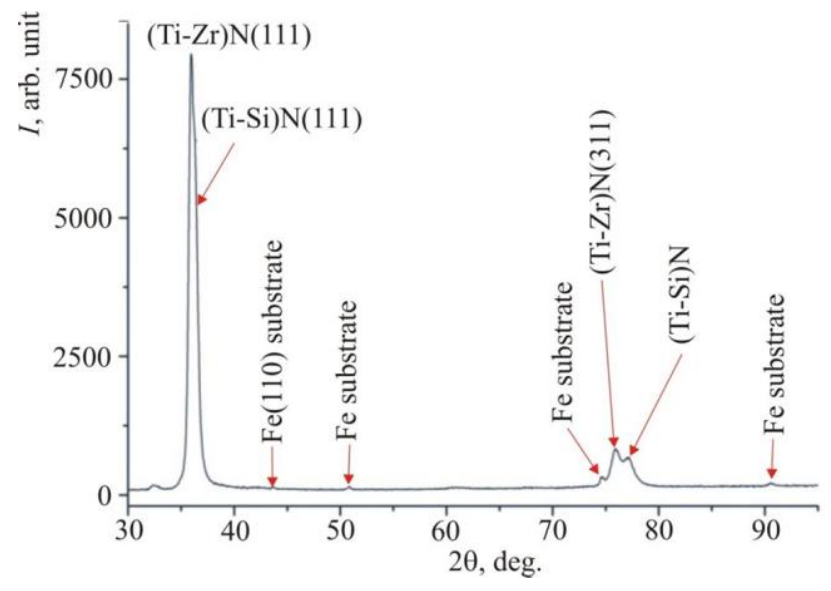

b

Fig. 4 - Regions of XRD spectra of (TiZr)N/(TiSi)N multilayer coatings obtained at $U_{b}=-200 \mathrm{~V}: \quad$ a) $P_{\mathrm{N}}=0.13 \mathrm{~Pa}$; b) $P_{\mathrm{N}}=0.6 \mathrm{~Pa}$

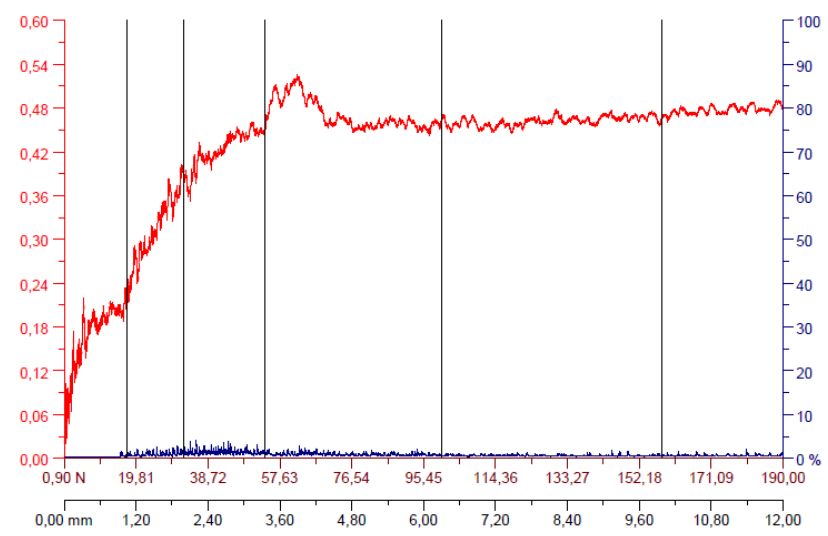

Substructural characteristics of the first series samples have been defined (Table 1). The TiZrN cubic lattice parameter is $0.4335 \mathrm{~nm}$, the size of the coherent scattering region of this phase is significantly lower and makes $D=42.1 \mathrm{~nm}$ at the level of microdistortions $\varepsilon=4.54 \times 10^{-3}$.

For the second series of samples, the parameter of the TiZrN lattice is $0.435 \mathrm{~nm}$, the coherent scattering region is the size of $D=61.1 \mathrm{~nm}$ at the level of microdistortions $\varepsilon=3.88 \times 10^{-3}$. The lattice parameter for the TiSiN is $0.429 \mathrm{~nm}$, the coherent scattering region of this phase is the size of $D=35.4 \mathrm{~nm}$ at the level of microdistortions $\varepsilon=6.30 \times 10^{-3}$.

The analysis of substructural characteristics shows that the increase of pressure of nitrogen atmosphere results in the increase of an average size of TiZrN crystallites in the coating, which is confirmed by the increase of the dimensions of the coherent scattering region. Along with this, the microdeformation of particles of this phase decreases. It is typical for the second phase, that the average size of crystallites also increases, but it goes along with an increase in microdistortions. Silicon additives contribute to an increase of nitride formation, although in all deposition modes the amount of silicon does not exceed 1 At\% (Table 1). The small amount of silicon prevents coating delamination with SiNx phase formation [8,9] which is confirmed by an absence of peaks from such phases in diffraction spectra (Fig. 4).

It is known that the most universal characteristic of mechanical properties of coatings is their hardness. The coating microhardness estimated at the indentation load of $50 \mathrm{~g}$ was $29.6 \mathrm{GPa}$ for the first series and 37.1 GPa for the second series.

The findings of sclerometric tests of the adhesive strength of coatings are shown in Fig. 5 and 6.

When performing scratch testing of coatings obtained at different pressures of nitrogen, similar changes in both friction coefficients and acoustic emission parameters were registered. The friction coefficients grow rather rapidly and steadily up to 55-60 N, after which they slightly decrease and then stay practically unchanged until the loading finishes. The acoustic emission level is rather low, the first noticeable peaks are registered starting from a load of $15 \mathrm{~N}$. The emission

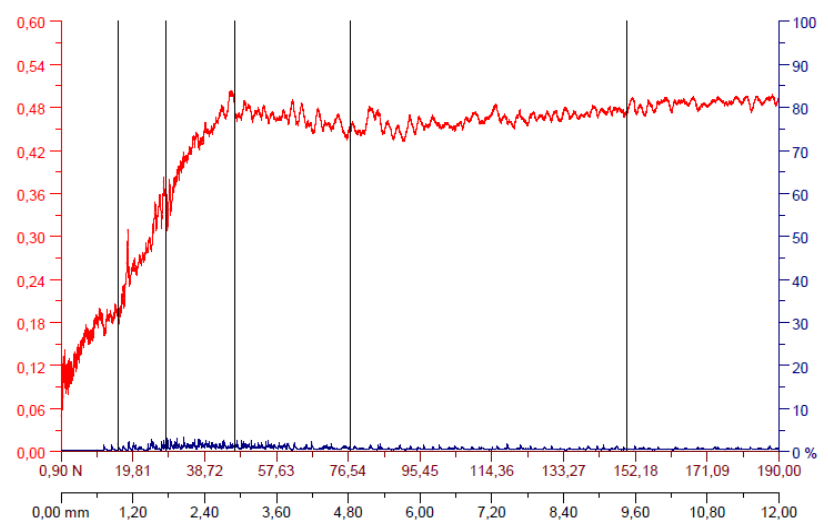

Fig. 5-Change of friction coefficient (red line) and acoustic emission (blue line) during scratch testing of samples with (TiZrN)N/(TiSi)N coating: a) $P_{\mathrm{N}}=0.13 \mathrm{~Pa}$; b) $P_{\mathrm{N}}=0.6 \mathrm{~Pa}$ 


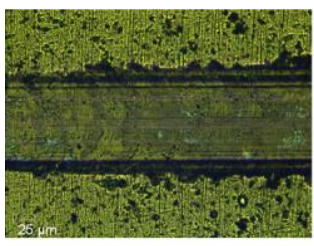

$\mathrm{LC1}$

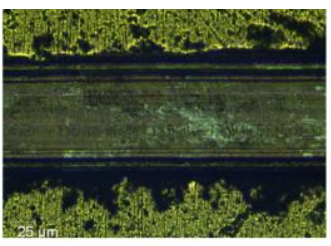

$\mathrm{LC} 2$

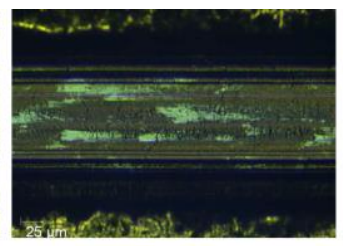

Lc3

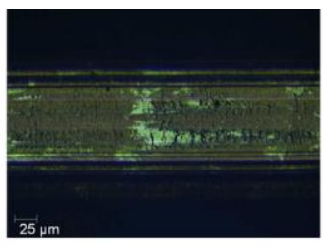

$\mathrm{LC}_{4}$

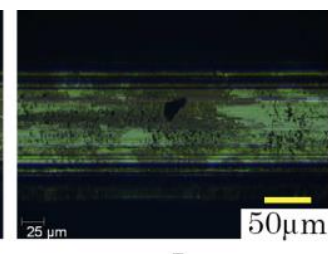

LC5

Fig. 6 - Zones of contact of the diamond indentor with $(\mathrm{TiZrN}) \mathrm{N} /(\mathrm{TiSi}) \mathrm{N}$ coating obtained at $P_{\mathrm{N}}=0.6 \mathrm{~Pa}$

curves for all types of coatings are smooth, with no extreme peaks, which is typical for wear without brittle fracture. The wear in all coating areas is smooth (Fig. 6) and with no well-defined cleavages, which is typical for plastic abrasion. This kind of wear is observed until the coating is fully worn down to the substrate (Fig. 6, Lc5).

The tests of the adhesive strength of multilayer coatings have shown that their wear goes smoothly with no cascade cleavages, which is confirmed by the acoustic emission data (Fig. 5). When scratched, the coatings get worn out but do not peel off, which is the evidence that the cohesion mechanism related to plastic deformation and fatigue facture in the coating material is implemented $[10,11]$.

The friction coefficient at $\mathrm{L}_{\mathrm{C} 4}-\mathrm{L}_{\mathrm{C} 5}$ for all systems makes about 0.46-0.45

\section{CONCLUSION}

(TiZrN)N/(TiSi)N multilayer coatings formed by vacuum arc deposition at different reactive gas pressures have the hardness of 29.6-37.1 GPa, where the lower hardness corresponds to the nitrogen pressure of $0.13 \mathrm{~Pa}$, and the higher hardness corresponds to the pressure of $0.6 \mathrm{~Pa}$. Coatings obtained at different nitrogen pressures and high bias potential of $-200 \mathrm{~V}$ demonstrate similar characteristics when undergoing adhesion scratch tests. The best coatings with regard to their mechanical properties were obtained at the nitrogen pressure of $0.6 \mathrm{~Pa}$ - their adhesive strength exceeds $150 \mathrm{~N}$. The proven technological process of coatings formation ensures their high uniformity and a low defect rate.

\title{
Багатошарові наноструктуровані покриття (TiZr)N / (TiSi)N, сформовані методом вакуумно-дугового осадження
}

\section{С.В. Литовченко ${ }^{1}$, Б.О. Мазілін ${ }^{1}$, В.М. Береснев ${ }^{1}$, В.О. Столбовий ${ }^{2}$ М.Г. Ковалева ${ }^{3}$, О.В. Крицина ${ }^{3}$ І.В. Колодій ${ }^{2}$, О.В. Глухов ${ }^{4}$, Л.В. Маліков ${ }^{5}$}

\author{
${ }_{1}$ Харківський національний університет ілені В. Н. Каразіна, Харків, Україна \\ 2 Національний науковий иентр "Харківський фбізико-технічний інститут», Харків, Украйна \\ ${ }_{3}$ Белгородський державний національний дослідницький університет, Белгород, Російська Федерація \\ 4 Харьковскій національний університет радіоелектроніки, Харків, Україна \\ 5 Науковий фбізико-технологічний центр МОН та НАН України, Харків, Україна
}

Досліджено структуру та властивості наномасштабних багатошарових покриттів на основі (TiZr)N та (TiSi)N, сдрормованих ваккумно-дуговим методом. Проаналізовано вплив парціального тиску азоту на структурно-фазовий стан покриттів. Нітридні фрази е сильно текстурованими, кристалографічні площини (111) більшості зерен орієнтовані паралельно до поверхні. Розраховано розміри областей когерентного розсіювання і рівні мікроспотворень гратів. Твердість покриттів досягала 37,1 ГПа, а навантаження адгезійного руйнування перевищуе 150 Н. Технологія процесу забезпечуе високу однорідність і низьку дефектність сформованого покриття.

Ключові слова: Нітридні покриття, Багатошарове покриття, Елементний склад, Структура, Мікротвердість, Адгезійна міцність.

\section{REFERENCES}

1. N.A. Azarenkov, O.V. Sobol, V.M. Beresnev, A.D. Pogrebnyak, D.A. Kolesnikov, P.V. Turbin, I.N. Toryanik, Metallofizika $i$ Noveishie Tekhnologii $\mathbf{3 5}$ No 8, 1061 (2013).

2. V.M. Beresnev, O.V. Sobol, D.A. Kolesnikov, G.V. Kirik, A.K.M. Muhammed, P.V. Turbin, V.V. Grudnitskiy, I.N. Toryanik, U.S. Nyemchenko, Metallofizika $i$ Noveishie Tekhnologii 34 No 2, 139 (2012).

3. Наноструктурные покрытия (Ред. А. Кавалейро и Д. де Хоссона) (Москва: Техносфера, 2011) (Nanostrukturnyye pokrytiya (Red. A. Kavaleyro i D. de Khossona) (Moskva: Tekhnosfera, 2011)) [In Russian].
4. V.M. Beresnev, O.V. Sobol,
A.D. Pogrebnjak, S.V. Lytovchenko,
P.A. Srebniuk,
V.Ju. Novikov, I.V. Doshchechkina, A.A. Meylehov, A.A. Postelnyk, U.S. Nyemchenko, B.A. Mazylin, V.V. Kruhlova, J. Nano- Eectron. Phys. 9 No 1, 01033 (2017).

5. A.D. Pogrebnjak, D. Eyidi, G. Abadias, O. V. Bondar, V. M. Beresnev, O. V. Sobol, Int. J. Refract. Met. Hard Mater. 48, 222 (2015).

6. T. Moria, M. Noborisakaa, T. Watanabeb and T. Suzukia, Surf. Coat. Technol. 213, 216 (2012).

7. A.D. Pogrebnjak, O.M. Ivasishin, V.M. Beresnev, Usp. Fiz. Met. 17, 1 (2016).

8. S. Veprek, M. Veprek-Heijman, P. Karvankova, J. Prochazka, Thin Solid Films 476, 1 (2005).

9. O.V. Sobol, A.D. Pogrebnjak, V.M. Beresnev, Phys. Met. 
Metallogr. 112 No 2, 188 (2011).

10. K.V. Smyrnova, A.D. Pogrebnjak, V.M. Beresnev, S.V. Litovchenko, S.O. Borba-Pogrebnjak, A.S. Manokhin, S.A. Klimenko, B. Zhollybekov, A.I. Kupchishin, Ya.O. Kravchenko, O.V. Bondar, Met. Mater. Int. 24 No 5, 1024 (2018)
11. V.M. Beresnev, O.V. Sobol, A.D. Pogrebnjak, S.V. Litovchenko, S.A. Klimenko, V.A. Stolbovoy, P.A. Srebniuk, A.S. Manokhin, M.G. Kovaleva, V.Yu. Novikov, A.A. Meilekhov, U.S. Nemchenko, A.E. Barmin, P.V. Turbin, Inorg. Mater.: Appl. Res. 9 No 3, 410 (2018). 